Studia Theologica Varsaviensia UKSW

$2 / 2020$

Karol Kisiel

\title{
DEMONICZNA POKUSA WEDŁUG MORALIÓW ŚW. GRZEGORZA WIELKIEGO
}

\section{WSTĘP}

Starożytna sztuka wojenna uczy: Kto zna wroga i zna siebie, nie będzie zagrożony choćby $i w$ stu starciach. Kto nie zna wroga, ale zna siebie, czasem odniesie zwycięstwo, a innym razem zostanie pokonany. Kto nie zna ani wroga, ani siebie, nieuchronnie ponosi klęske w każdej walce ${ }^{1}$ Ta myśl, choć wyrażona przez postać odległą geograficznie od starożytnego monastycyzmu, dobrze oddaje podstawę chrześcijańskiej demonologii. Nie jest ona wynikiem niezdrowej fascynacji szatanem, lecz ma na celu przygotowanie do walki przez poznanie swojego wroga i sposobów jego działania. Walka ze złem, które reprezentuje szatan, na przestrzeni wieków nigdy nie straciła na swojej aktualności, więc i chrześcijańska nauka o pokusach także w dzisiejszych czasach ma duże znaczenie w życiu wierzących.

W Moraliach Grzegorza Wielkiego spotyka się niezwykłe bogactwo myśli na temat kuszenia człowieka. Jedną z przyczyn pokusy jest działanie demoniczne. Podejmuję się zatem zagadnienia demonicznej przyczynowości pokusy. Według mojej wiedzy ten wątek nie został przez nikogo jeszcze szczegółowo opracowany na podstawie wspomnianego monumentalnego dzieła papieża.

\footnotetext{
1 Sun Tzu, Sun Pin, Sztuka Wojny, Gliwice 2014, 26.
} 


\section{DEMONIC TEMPTATION ACCORDING TO MORALS ON THE BOOK OF JOB OF ST GREGORY THE GREAT}

\section{PREFACE}

The ancient art of war teaches: If you know the enemy and know yourself, you need not fear the result of a hundred battles. If you know yourself but not the enemy, for every victory gained you will also suffer a defeat. ${ }^{1}$ This thought, although expressed by an author from a geographic location far from ancient monasticism, well reflects the basis of Christian demonology. It is not the result of some unhealthy fascination with Satan, but is intended to prepare for battle by knowing one's enemy and how they work. The fight against the evil that Satan represents has never lost its relevance over the centuries, so the Christian doctrine of temptation is also very important in the lives of believers today.

In Morals of Gregory the Great one encounters an extraordinary wealth of thoughts about tempting man. One of the causes of temptation is demonic action. Hence the author addresses the issue of the demonic causality of temptation. To his knowledge, this theme

1 Sun Tzu, Sun Pin, The Art of War, Translator: Lionel Giles; Release Date: May 1994 [eBook 132] [Most recently updated December 28, 2005], p.32 


\section{CELOWOŚĆ POKUSY DEMONICZNEJ}

Aby zrozumieć to, dlaczego złe duchy nieustannie działają na ludzką szkodę, trzeba cofnąć się do momentu upadku części aniołów. Św. Grzegorz Wielki porównuje ze sobą grzech i winę ludzi oraz aniołów. Jako element wspólny dla obu upadków wskazuje pychę: Uczynit bowiem dwa rodzaje stworzeń, aby Go poznaty, mianowicie anielski i ludzki; obydwa jednak dotknęła srodze pycha i zniszczyła $w$ nich stan wrodzonej prawości $i^{2}$. Między grzechem pychy ludzi i aniołów są jednak dwie zasadnicze różnice po stronie podmiotu. Po pierwsze, ludzie posiadają ciało i są mniej doskonali od czysto duchowych aniołów. Po drugie, aniołowie sami z siebie popadli w grzech, a ludzie z powodu niegodziwości szatana. Stąd ludzie, w których grzechu miała udział naturalna słabość i kuszenie ze strony diabła, zaciągnęli mniejszą winę niż aniołowie. Mogą oni zatem uzyskać odpuszczenie grzechów, a upadli aniołowie - nie 3 .

Grzech pychy i z nim związana chęć osiągnięcia najwyższej władzy i chwały najlepiej określa szatana. Diabeł chciał stać się podobny Stwórcy, a nawet większy od Niego, co święty odczytuje w satyrze o upadku króla, zapisanej w Księdze Izajasza. Fragment tej satyry: Zasiądę na Górze Ś wiadectwa, na pótnocy: wespnę się nad wysokość chmur, będę podobny do Najwyższego ${ }^{4}$, doktor Kościoła w Moraliach cytuje aż 19 razy, zawsze odnosząc go do szatana, by przypomnieć i uwydatnić, iż pierwszym największym grzechem jest pycha i to ona charakteryzuje tego, który namawia innych do zła ${ }^{5}$.

Złe duchy, które przez swoją winę utraciły chwałę i łaskę Bożą ${ }^{6}$, starają się nie pozwolić ludziom na uzyskanie tego, co ludzie utracili przez grzech pierwszych rodziców. Dlatego pierwszym

2 Grzegorz Wielki, Moralia, IV, III, 8, ŹMon 39, 300.

3 Cfr. Ibidem, IV, III, 8, ŹMon 39, 300-301.

${ }^{4}$ Iz 14, 13-14.

5 Cfr. Grzegorz Wielki, Moralia, XXIII, VI, 13, ŹMon 75, 24.

${ }^{6}$ Cfr. Ibidem, III, XXXI, 60, ŹMon 39, 277; XXXI, XLIX, 99, ŹMon 77, 334-335. 
has not yet been developed in detail by any other scholar based on the aforementioned monumental work of the Pope.

\section{PURPOSEFULNESS OF DEMONIC TEMPTATION}

To understand why evil spirits constantly act against people, it is necessary to go back to the fall of some angels. St Gregory the Great compares the sin and guilt of people and angels with each other. As a common element in both falls, he points out pride: Now he had made two creations to contemplate Himself, viz. the Angelic and the human, but Pride smote both, and dashed them from the erect station of native uprightness. ${ }^{2}$ However, there are two fundamental differences between the sinful pride of men and angels. Firstly, people have a body and are less perfect than purely spiritual angels. Secondly, angels themselves became sinners, and humans because of Satan's wickedness. Hence, people whose sin was due to natural weakness and temptation on the part of the devil bore less blame than angels. They can therefore obtain remission of their sins, whereas the fallen angels - no $^{3}$.

The sin of pride and the desire to achieve supreme power and glory associated with it is best described by Satan. The devil wanted to be like the Creator, or even greater than him, as the Saint reads in the satire on the fall of the King, written in the Book of Isaiah. A fragment of this satire says: I will sit on the mount of assembly in the far reaches of the north; 14 I will ascend above the heights of the clouds; I will make myself like the Most High ${ }^{4}$. The Doctor of the Church in Morals quotes it as many as 19 times, always referring to Satan, to remind us that the first greatest sin is pride, and it is pride that characterises the one who persuades others to evil doings. ${ }^{5}$

\footnotetext{
2 St Gregory the Great, Morals on the Book of Job, IV, III, 8, OXFORD, JOHN HENRY PARKER; J.G.F. I J. RIVINGTON, LONDYN. 1844, 300.

${ }^{3}$ Cf. Ibidem, IV, III, 8, 300-301.

${ }^{4}$ Isaiah 14, 13-14.

5 Cf. St Gregory the Great, Morals..., XXIII, VI, 13, ŹMon 75, 24.
} 
i podstawowym motywem wszystkich pokus jest nienawiść złych duchów do ludzi. Ta złość kierująca szatanem sprawia, iż autor Moraliów określa go jako dzikie zwierzę, które w swym okrutnym szale [pragnie] oszukać pierwszego człowieka ${ }^{7}$. Mówiąc o okrutnym szale, doktor Kościoła nie twierdzi, że metody działania złych duchów są nierozumne. Użyte przez niego określenia mają podkreślić kontrast między sprawiedliwością Boga i szałem szatana. Postępowanie Boga jest zatem motywowane pragnieniem dobra ludzi. Złe duchy natomiast podejmują destrukcyjne akty wymierzone przeciwko ludziom z czystej złośliwości i nienawiści do tych, którzy jeszcze nie utracili swojej możliwości zbawienia.

Nie ulega wątpliwości, że podstawową przyczyną działań złych duchów przeciw ludzkości jest złość i pragnienie przeciwstawienia się Bogu. Jednakże św. Grzegorz nie poprzestaje na tej prawdzie, ale wskazuje także inny powód, którym jest demoniczna żądza władzy. Autor Moraliów zauważa, że diabeł zgrzeszył pychą, która jest korzeniem wszelkiego grzechu i w skutek tego popadł we wszystkie jej rozgałęzienia ${ }^{8}$. Wada pociąga zatem za sobą inne wady także u istot duchowych. Pycha szatana sprawiła, że opanowany został także przez inne wady. Jedną z konsekwencji tego stanu jest właśnie żądza władzy, którą charakteryzuje się zły duch.

Myśl doktora Kościoła dotycząca władzy szatana nad niegodziwymi ludźmi nacechowana jest postrzeganiem świata jako pola walki. Ścierają się na nim Bóg i złe duchy, walcząc o dusze ludzi9. Dostrzegając Boga i wierzących, którzy stanowią corpus Christi, autor dochodzi do wniosku, że także szatan i nieprawi, będąc antytezą wierzących chrześcijan skupionych wokół Chrystusa, stanowią swego rodzaju społeczność. Charakterystyki tego zgromadzenia

\footnotetext{
7 Ibidem, XXVII, XXVI, 49, ŹMon 75, 337.

8 Cfr. Ibidem, XXXIV, XXIII, 47, ŹMon 78, 152.

9 Cfr. G. Cremascoli, Corpus diaboli. Sulla demonologia di Gregorio Magno w: Il diavolo nel medioevo. Atti del XLIX Convegno storico internazionale. Todi, 14-17 ottobre 2012, Spoleto 2013, 55-56.
} 
Evil spirits who, through their guilt, lost God's glory and grace, try to prevent people from getting what they lost through the sin of their first parents. Therefore, the first and basic motive for all temptations is hatred of people by evil spirits. This anger that drives Satan makes the author of Morals describe him as the beast, (...) who cruelly aimed at the deception of the first $\mathrm{man}^{6}$. Speaking of cruel malice, the Doctor of the Church does not claim that the methods of evil spirits are incomprehensible. The terms he uses are intended to highlight the contrast between God's justice and Satan's rage. God's conduct is therefore motivated by a desire for the good of people. On the other hand, evil spirits undertake destructive acts against people out of pure malice and hatred for those who have not yet lost their chance of salvation.

There is no doubt that the primary cause of the evil spirits' actions against humanity is anger and a desire to oppose God. However, St. Gregory does not confine himself to this truth, but also points to another reason, which is a demonic lust for power. The author of Morals notes that the devil sinned with pride, which is the root of all sin, and consequently fell into all its branches ${ }^{7}$. A flaw therefore entails other flaws in spiritual beings too. Satan's pride brought about other vices too. One of the consequences of that state is precisely the lust for power, which is typical of an evil spirit.

The thought of the Doctor of the Church about the power of Satan over wicked people is characterised by a perception of the world as a battlefield. God and evil spirits clash on it, fighting for the people' souls. ${ }^{8}$ Seeing God and the believers who are the corpus Christi, the author comes to the conclusion that Satan and the unrighteous, being the antithesis of Christian believers cantered around Christi, also constitute a kind of community. The characteristics of this

6 Ibidem, XXVII, XXVI, 49, ŹMon 75, 337.

7 Cf. Ibidem, XXXIV, XXIII, 47, ŹMon 78, 152.

${ }^{8}$ Cf. G. Cremascoli, Corpus diaboli. Sulla demonologia di Gregorio Magno w: Il diavolo nel medioevo. Atti del XLIX Convegno storico internazionale. Todi, 14-17 ottobre 2012, Spoleto 2013, 55-56. 
dokonuje on w kontraście tej społeczności do wspólnoty świętych ${ }^{10}$. Istoty te, nieustannie przeciwstawiające się Bogu, to corpus diaboli ${ }^{11}$, z szatanem jako głową. Aby lepiej zrozumieć celowość działania złych duchów, należy prześledzić czym dokładnie jest corpus diaboli i w jaki sposób człowiek staje się jego częścią.

Najbardziej widocznym przejawem społeczności nieprawych będzie jawne panowanie Antychrysta, człowieka opętanego przez samego szatana ${ }^{12}$. Autor Moraliów wielokrotnie opisuje niezwykłą grozę czasu największych prześladowań, które zakończą się ostatecznym przyjściem Chrystusa ${ }^{13}$, jednak nie ogranicza działania corpus diaboli jedynie do tego okresu. Przywołując liczne przykłady biblijne, wskazuje, że wielu nie widziało czasu tego kuszenia, a jednak zostali wciagnięci w jego burzę ${ }^{14}$. Zatem władza szatana nad ludźmi, choć udzielona w pełni pod koniec świata, nieustannie oddziałuje na nich w historii.

Grzegorz Wielki używa przede wszystkim dwóch obrazów na ukazanie, w jaki sposób człowiek uczestniczy na ziemi w corpus diaboli. Pierwszy z nich, obraz przebywania złego ducha w mieszkaniu serca (habitaculum cordis), dotyczy opanowania człowieka przez pokusę, które nosi w sobie duże podobieństwo do opętania. Drugi z nich wyraża podobieństwo do szatana i jego wad.

Po grzechu pierworodnym człowiek jest podatny na różnego rodzaju pokusy. Wkradają się one nieustannie między dobre myśli

${ }^{10}$ Cfr. Ibidem, 58; Grzegorz Wielki, Moralia, XIII, X, 13, ŹMon 44, 126.

11 Choć sama nazwa nie pojawia się w pismach doktora Kościoła, to jednak wcześniej została użyta przez św. Augustyna (zob. Augustyn, Enarrationes in Psalmos, 73, 16, PL 36, 938), a św. Grzegorz Wielki używa określeń corpus, mając na myśli tę społeczność (zob. Grzegorz Wielki, Moralia, XXXII, XIV, 21, CCL 143B). Określenie membra diaboli używane kilkukrotnie przez autora oznacza jedynie część tego corpus diaboli. Cfr. Grzegorz Wielki, Moralia, XIII, X, 12, CCL 143A; S. Rosik, Finalizm życia chrześcijańskiego w świetle twórczości papieża Grzegorza Wielkiego, Lublin 1980, 97.

${ }_{12}$ Cfr. Grzegorz Wielki, Moralia, XXXII, XV, 22, ŹMon 77, 376.

13 Cfr. ibidem, XXIX, VI, 11, ŹMon 77, 76.

14 Ibidem, XXIX, VII, 15, ŹMon 77, 80. 
congregation are in contrast to the community of saints ${ }^{9}$. These beings, constantly opposing God, are corpus diabolit ${ }^{10}$, with Satan as its head. In order to better understand the purpose of evil spirits, it is necessary to trace what exactly the corpus diaboli is and how man becomes part of it.

The most visible manifestation of the community of the unvirtuous is the open reign of the Antichrist, a man possessed by Satan himself. ${ }^{11}$ The author of Morals reiterates the extraordinary horror of the time of the greatest persecution, which will end up with the final coming of Christ ${ }^{12}$, yet he does not limit the activities of the corpus diaboli to this period alone. Recalling numerous biblical examples, he points out that how many have beheld not the times of that temptation, and yet are involved in the storm of his temptation. ${ }^{13}$ Recalling numerous biblical examples, he points out that many did not see the time of this temptation, and yet were dragged into its storm. Thus, the power of Satan over people, although fully granted towards the end of the world, continually influences them in history.

Gregory the Great uses primarily two images to show how man participates in the corpus diaboli on earth. The first one, the image of the presence of an evil spirit in the dwelling-place of our heart (habitaculum cordis), concerns the control of man by temptation, which bears great resemblance to possession. The second of them expresses the resemblance to Satan and his vices.

\footnotetext{
9 Cf. Ibidem, 58; St Gregory the Great, Morals..., XIII, X, 13, ŹMon 44, 126.

${ }_{10}$ Although the name itself does not appear in the writings of the Doctor of the Church, it was previously used by St Augustine (see Augustine, Enarrationes in Psalmos, 73, 16, PL 36, 938), and St Gregory the Great uses the term corpus with reference to this community (see St Gregory the Great, Morals..., XXXII, XIV, 21, CCL 143B). The term membra diaboli used several times by the author means only part of corpus diaboli. Cf. St Gregory the Great, Morals..., XIII, X, 12, CCL 143A; S. Rosik, Finalizm życia chrześcijańskiego w świetle twórczości papieża Grzegorza Wielkiego, Lublin 1980, 97.

${ }^{11}$ Cf. St Gregory the Great, Morals..., XXXII, XV, 22, ŹMon 77, 376.

${ }^{12}$ Cf. ibidem, XXIX, VI, 11, ŹMon 77, 76.

13 Ibidem, XXIX, VII, 15, ŹMon 77, 80.
} 
człowieka, lecz od ludzkiej zgody zależy, czy grzech zdobędzie panowanie w mieszkaniu serca ${ }^{15}$. To przyzwolenie na grzech sprawia, że Bóg odbiera człowiekowi swoją łaskę chroniącą przed złem, a grzesznik otwiera swe serce na diabła, który posiada je jak własna jame za sprawa ukrytej niegodziwości $i^{16}$.

Posiadając mieszkanie w sercu człowieka, szatan może działać na szkodę ludzi w każdym czasie i miejscu. Przykładem tego szkodliwego działania są Żydzi, w których cały czas potajemnie zamieszkiwał zły duch, a w czasie sądu nad Jezusem krzyczał przez nich: Ukrzyżuj, ukrzyżuj!! ${ }^{17}$. Nie oznacza to jednak, że jedynie szatan ponosi winę za złe czyny ludzi. Nieprawi stają się częścią corpus diaboli przez zgodę na zło i upodobanie w nim. W związku z tym słusznie zostaną za swoje czyny ukarani, bo przecież każdego dnia źli ludzie sprzyjaja sprawie Antychrysta, gdyż już teraz skrycie dokonuje $w$ ich sercach swojej tajemnicy ${ }^{18}$. Doktor Kościoła pragnie jednak podkreślić, że zło ma swoje źródło w czynach szatana. Działa on przez posłusznych mu grzeszników ${ }^{19}$, którzy poddając się pod jego panowanie stają się narzędziem oddziaływania na świat przez złe czyny, co jest głównym celem demonów ${ }^{20}$.

Uczestnictwo w corpus diaboli św. Grzegorz Wielki określa także jako naśladowanie szatana. Grzeszący człowiek przestaje swoimi czynami naśladować Boga, lecz nabywa podobieństwo do złego ducha i związuje się z nim przez swoje uczynki ${ }^{21}$. Ulegając złym duchom

${ }^{15}$ Cfr. ibidem, XXI, III, 7, ŹMon 63, 333-334; XXVII, XXVI, 49, ŹMon 75, 338. Autor podkreśla w tym miejscu odebranie łaski przez Boga, by czytelnik nie sądził, iż złe duchy zwyciężają ze Stwórcą. Wszechmocny sprawiedliwie karze człowieka za grzech pozostawiając go samemu wobec ataków pokus. Jeśli człowiek się nawróci, wtedy odebrana łaska powróci.

${ }^{16}$ Ibidem, XXVII, XXVI, 49, ŹMon 75, 337.

17 J 19, 6. Cfr. Grzegorz Wielki Moralia, XXVII, XXVI, 49, ŹMon 75, 337-338.

18 Ibidem, XXIX, VII, 17, ŹMon 77, 83.

19 Cfr. Ibidem, XXVII, X, 16, ŹMon 75, 297-298; O. Kashchuk, Księga Rodzaju jako źródło duchowej inspiracji w „,Moralia in Iob” św. Grzegorza Wielkiego, „Biblica et Patristica Thoruniensia” 4 (2011), 359-360.

${ }^{20}$ Cfr. Grzegorz Wielki, Moralia, XXVII, XXVI, 49, ŹMon 75, 337.

${ }^{21}$ G. Cremascoli, op. cit., 58. 
After original sin, man is susceptible to various types of temptation. They constantly sneak in between man's good thoughts, but it depends on human consent whether or not sin will gain dominion in the dwelling-place of our heart ${ }^{14}$. This consent to sin makes God take away from man his grace to protect him from evil, and the sinners open their heart to the devil, who possesses $[$ them $]$ (...) and occupies them by his secret wickedness, as though they were his own den. ${ }^{15}$

Having a dwelling-place in the heart of man, Satan can act to the detriment of people at any time and in any place. An example of such harmful acts are the Jews, in whom an evil spirit was secretly dwelling all the time, and who shouted through them during the judgment over Jesus: Crucify, crucify!16. However, this does not mean that only Satan is to blame for people' bad acting. The unrighteous become part of the corpus diaboli by agreeing to wickedness and liking to it. Therefore, it is right that they would be punished for their actions, for the cause of Antichrist is continually promoted among the ungodly, because he is even now secretly working his mystery in their hearts. ${ }^{17}$ However, the Doctor of the Church stresses that wickedness has its source in the deeds of Satan. He acts through obedient sinners ${ }^{18}$, who, by submitting to his reign, become a tool to influence the world through evil acts, which is the main purpose of demons. ${ }^{19}$

${ }^{14}$ Cf. ibidem, XXI, III, 7, ŹMon 63, 333-334; XXVII, XXVI, 49, ŹMon 75, 338. At this point, the author stresses that God's grace is taken away, so that the reader does not think that evil spirits win with the Creator. The Almighty justly punishes man for sin, leaving him alone in the face of attacks of temptation. If man repents, then the grace he has received will return.

15 Ibidem, XXVII, XXVI, 49, ŹMon 75, 337.

16 J 19:6. Cf. St Gregory the Great, Morals..., XXVII, XXVI, 49, ŹMon 75, 337-338.

17 Ibidem, XXIX, VII, 17, ŹMon 77, 83.

${ }^{18}$ Cf. Ibidem, XXVII, X, 16, ŹMon 75, 297-298; O. Kashchuk, Księga Rodzaju jako źródło duchowej inspiracji w „,Moralia in Iob” św. Grzegorza Wielkiego, „Biblica et Patristica Thoruniensia” 4 (2011), 359-360.

19 Cf. St Gregory the Great, Morals..., XXVII, XXVI, 49, ŹMon 75, 337. 
człowiek uczestniczy w rozprzestrzenianiu się zła jeszcze długo przed epoką prześladowań Antychrysta. Przykładem jest Szymon Mag, który byt daleki od czasów Antychrysta, a jednak połaczyt się z jego pycha, gdyż przewrotnie zapragną władzy czynienia cudów $w^{22}$.

Każdy grzech jest naśladowaniem szatana, nawet jeśli zły duch nie popełnia tego rodzaju występku osobiście. Fundamentem wszystkich grzechów jest pycha grzeszącego, więc człowiek grzeszący obżarstwem, choć nie powtarza konkretnego czynu złego ducha, to naśladuje jego pychę. Tym samym istotą podobieństwa człowieka do szatana nie jest sam zły czyn, lecz jego ukryty korzeń, którym jest pycha ${ }^{23}$.

Naśladowanie złego ducha skutkuje zgodnością w działaniu między ludźmi grzeszącymi. Ta zgodność sprawiła, że Kościół w Tiatyrze został oskarżony o postępowanie według nauk Jezebel ${ }^{24}$, choć dzielił go od niej czas i miejsce. Podobnie Jan Apostoł stwierdza, że obecnie powstało wielu Antychrystów ${ }^{25}$, wskazując na jedność działania heretyków i Antychrysta. Te fragmenty Pisma Świętego prowadzą św. Grzegorza Wielkiego do wniosku: Dlatego zdarza się, że pośród swoich przewrotnych naśladowców przebywa każdy nieprawy, który już umart, jak i sprawca nieprawości, który jeszcze nie nadszedt, da się już widzieć $w$ tych, którzy czynia jego uczynki². Przez to obrazowe stwierdzenie doktor Kościoła podkreśla łączność nieprawych w złym postępowaniu. Każdy grzesznik jest częścią całego łańcucha zła dokonującego się przez wieki. Dawne zło ośmiela i daje przykład ludziom żyjącym obecnie, więc można powiedzieć, że dawny grzesznik jest obecny wśród swych późniejszych towarzyszy w złu. Każdy obecny grzech jest przykładem i zachętą dla przyszłych pokoleń do dalszego, jeszcze większego zła, co św. Grzegorz Wielki wyraża przez obecność sprawcy nieprawości, który jeszcze nie nadszedt. W ten

\footnotetext{
22 Grzegorz Wielki, Moralia, XXIX, VII, 15, ŹMon 77, 80.

${ }^{23}$ Cfr. Ibidem, XXIV, XXIII, 47, ŹMon 75, 152; XXIV, XXV, 52, ŹMon 75, 129.

${ }^{24}$ Cfr. Ap 2, 20.

$251 \mathrm{~J} 2,18$.

26 Grzegorz Wielki, Moralia, XXIX, VII, 15, ŹMon 77, 81.
} 
St. Gregory the Great also describes participation in the corpus diaboli as imitation of Satan. A sinner ceases to imitate God with his actions, but acquires a likeness to the evil spirit and is bound to it by his acting. By yielding to the evil spirits, man participates in the spread of wickedness long before the time of persecution of the Antichrist. An example is Simon Magus, was far removed from the times of Antichrist, and yet joined himself to his pride, by perversely seeking for the power of miracles. ${ }^{20}$

Every sin is an imitation of Satan, even if the evil spirit does not commit that kind of act personally. The foundation of all sins is the pride of the sinner, so who commits a sin of gluttony, though he does not repeat a particular act of the evil spirit, imitates his pride. Thus the essence of man's likeness to Satan is not the evil act itself, but its hidden root, which is pride. ${ }^{21}$.

Imitating an evil spirit results in a consensus in action between sinners. That kind of harmony led to the Church in Tiatyra being accused of following the teachings of Jezebel ${ }^{22}$, even though it was a time and place away from it. Hence John the Apostle states that now many antichrists have arisen ${ }^{23}$, pointing to the unity of action between heretics and the Antichrist. Following these texts from the Holy Scriptures St Gregory the Great concludes: Whence it is that every wicked person, who has already gone by, survives in his perverse imitators, and that the author of iniquity, who has not yet come, is already visible in those who do his works. ${ }^{24}$ With this illustrative statement, the Doctor of the Church emphasises the connectivity of the unrighteous in wicked doings. Every sinner is part of a whole chain of evil living that has been going on for centuries. The former wickedness dares and sets an example to the people who live today, so it can be said that the former sinner is present among his followers

\footnotetext{
20 St Gregory the Great, Morals..., XXIX, VII, 15, ŹMon 77, 80.

${ }^{21}$ Cf. Ibidem, XXIV, XXIII, 47, ŹMon 75, 152; XXIV, XXV, 52, ŹMon 75, 129.

${ }^{22}$ Cf. Ap 2, 20.

231 Jn 2: 18.

24 St Gregory the Great, Morals.., XXIX, VII, 15, ŹMon 77, 81.
} 
sposób zło i działanie szatana rozwija się, aż do osiągnięcia szczytu podczas panowania Antychrysta. Do tego rozwoju zła przyczyniają się w znacznym stopniu ludzie, a nie tylko złe duchy, dlatego Apokalipsa mówi o nauce Jezebel, a nie „nauce szatana”.

Powyższa zgodność przejawia się nie tylko w samym postępowaniu, lecz także w celu ludzkiego działania, gdyż ciało Lewiatana [szatana] to wszyscy nieprawi, którzy swoim pragnieniem nie wznosza się do poznania duchowej ojczyzny ${ }^{27}$. Gdy ludzie, pokonani przez pokusę, stają się w pełni częścią corpus diaboli i przestają pragnąć nieba, szatan w podwójny sposób osiąga swój cel. Przede wszystkim udaje mu się odebrać człowiekowi możliwość zbawienia, co jest ostatecznym celem pokusy. Ponadto przez ukierunkowanie człowieka przeciw Bogu złe duchy zyskują dodatkowe narzędzia, którymi będą atakować ludzi szukających zbawienia. Dlatego doktor Kościoła mówi o oczach i zębach szatana, którymi są źli ludzi obmyślający niegodziwości lub prześladujący chrześcijan ${ }^{28}$.

Autor Moraliów wskazuje także, iż demoniczne pokusy mogą osiągnąć skutek także wtedy, gdy człowiek się im opiera. Św. Grzegorz Wielki przedstawia złe duchy jako cudzoziemców, którzy z ukrycia zasypują studnię wykopywaną przez Izaaka ${ }^{29}$. Powyższe porównania wskazują na dwa cele szatańskiego działania. Zły duch przez swoje nieustanne ataki chce osłabić siłę woli człowieka i przez nieustanne kuszenie złamać ją lub znaleźć jej słaby punkt. Ponadto przez swoje złe namowy przeszkadza ludziom w rozwoju duchowym przez wypełnianie ich umysłów myślami pełnymi pokus. Bóg może być poznany tylko przez spokojne serce ${ }^{30}$, dlatego nawet człowiek

\footnotetext{
27 Ibidem, XXXIV, IV, 8, ŹMon 78, 111.

28 Cfr. Ibidem, XIII, X, 13, ŹMon 44, 126.

${ }^{29}$ Cfr. Rdz 26, 14-25; Grzegorz Wielki, Moralia, XXXI, XXVII, 53, ŹMon 77, 291.

${ }^{30}$ Grzegorz Wielki, Moralia, XXXIII, XXXVII, 63, ŹMon 78, 96. Św. Grzegorz Wielki porównuje w tym miejscu ziemskie myśli do dymu, przeszkadzającego w kontemplacji Stwórcy. Jest on zawsze obecny w umyśle ludzi światowych, lecz często atakuje też ludzi duchowych.
} 
in wickedness. Every single sin is an example and an encouragement to future generations to further, even greater wickedness, as St Gregory the Great expresses by the presence of the author of iniquity, who has not yet come. In this way, the wickedness and evil doings of Satan unfold until they reach their peak during the reign of the Antichrist. People, not just evil spirits, make a significant contribution to this development of wickedness, which is why the Apocalypse speaks of the doctrine of Jezebel, not the "doctrine of Satan".

The aforesaid concordance is manifested not only in the conduct itself, but also in the purpose of human action, since the 'flesh' of this Leviathan [Satan] are all the reprobate, who rise not in their longing to a knowledge of their spiritual country. ${ }^{25}$ When people, defeated by temptation, become fully part of the corpus diaboli and stop wanting heaven, Satan achieves his goal in a double way. First of all, he succeeds in taking away a man's opportunity for salvation, which is the ultimate goal of temptation. Furthermore, by directing man against God, evil spirits gain additional tools with which to attack people seeking salvation. That is why the Doctor of the Church speaks of the eyes and teeth of Satan, which are the evil people who devise wickedness or persecute Christians. ${ }^{26}$

The author of Morals further points out that demonic temptations can also be successful if man resists them. St. Gregory the Great presents evil spirits as aliens who secretly cover the well dug by Isaac $^{27}$. Such a comparison indicates two of the objectives of the devil's action. The evil spirit, through its constant attacks, wants to weaken the strength of human will and, through constant enticement, to break it or find its weakness. Furthermore, by its evil persuasions, it prevents people from developing spiritually by filling their minds with thoughts full of temptation. But God cannot be recognised, except by a tranquil

25 Ibidem, XXXIV, IV, 8, ŹMon 78, 111.

${ }^{26}$ Cf. Ibidem, XIII, X, 13, ŹMon 44, 126.

${ }^{27}$ Cf. Rdz 26, 14-25; St Gregory the Great, Morals..., XXXI, XXVII, 53, ŹMon 77, 291. 
opierający się grzesznym myślom ponosi pewne straty w walce ze złymi duchami.

Demony kuszą ludzi także z bardziej osobistych powodów. Otóż doktor Kościoła pyta retorycznie: Czy nie jest zabawa dla złych $d u$ chów, czy to zwodzić kłamliwymi obietnicami umysty ludzi, które zostaty stworzone na Boży obraz, czy to szydzić z nich nieprawdziwymi strachami ? $^{31}$. Wskazuje tym samym, że złe duchy czerpią pewnego rodzaju radość ze zwodzenia ludzi ku złu. Jest to przyjemność wynikająca ze zniszczenia dzieła Boga i posiadania nad nim władzy.

Ponadto ojciec Kościoła wspomina, iż dla demonów istotne jest, który zły duch skusi człowieka, gdyż w nagrodę otrzyma on duszę tego grzesznika, jednak nie precyzuje, na czym ta władza złego ducha nad potępionym polega ${ }^{32}$. W innym miejscu określa ludzi zatwardziałych w swej winie towarzyszami diabła ${ }^{33}$, lecz określenie to stosuje jedynie alegorycznie, więc nie należy z nich wnioskować o przyjacielskich relacjach w piekle. Koniec świata będzie jednak końcem tej zabawy złych duchów ${ }^{34}$, gdyż zbawieni nie będą mogli być kuszeni. Wtedy złe duchy będą podlegały już tylko cierpieniu pozbawione swojej jedynej ,przyjemności”35.

To działanie szatana nie może być jednak całkowicie niezależne od woli Stwórcy. Bóg i diabeł nie są równoważnymi sobie przeciwnikami, co wyraźnie ukazuje autor Moraliów. Podkreśla on niemal całkowitą zależność złych duchów od Boga, stwierdzając: przyzwala na wypróbowanie ich [sprawiedliwych] niewinności, niekiedy zaś powstrzymuje go, by nie ważyt się kusić3 ${ }^{36}$ Użycie określeń przyzwala i powstrzymuje ma na celu zakreślenie wyraźnej granicy między Stwórcą i stworzeniem. Walka podejmowana przez szatana i jego nienawiść do Wszechmocnego nie są w stanie mu zagrozić, gdyż

31 Ibidem, XXXIII, II, 4, ŹMon 78, 15.

32 Ibidem, XII, XXXIV, 39, ŹMon 44, 143-144.

33 Ibidem, XIII, XXXIV, 39, ŹMon 44, 144.

${ }^{34}$ Ibidem, XXXIII, II, 4, ŹMon 78, 15.

${ }^{35}$ Cfr. L. Nieścior, Implikacje moralne nauki o czasie w „,Moraliach” św. Grzegorza Wielkiego, „Teologia Patrystyczna” 2 (2005), 68.

${ }^{36}$ Grzegorz Wielki, Moralia, II, VII, 12, ŹMon 39, 157. 
heart, ${ }^{28}$ so even a man who resists sinful thoughts suffers certain losses in the fight against evil spirits.

Demons tempt people for more personal reasons too. The Church doctor asks rhetorically: Is it not sport for evil spirits, to deceive at one time by false promises the minds of men which were made after the image of God, at another to make mock at them with empty terrors? ${ }^{29}$. It thus indicates that evil spirits derive some kind of joy from deceiving people into evil. It is the pleasure of destroying God's work and having power over it.

Furthermore, the father of the Church mentions that it is important for demons to know which evil spirit will tempt man, for they will receive the soul of this sinner as a reward, but he does not specify what this power of the evil spirit over the condemned one consists in $^{30}$. He also refers to people who are obstinate in their guilt as associates of the devil ${ }^{31}$, but he uses this term only allegorically, so one should not assume that they have a friendly relationship in hell. However, the end of the world will be the end of the field of evil spirits ${ }^{32}$, for the saved will not be tempted. Then the evil spirits will be subject only to suffering without their only 'pleasure'.33

However, this action of the devil cannot be completely independent of the Creator's will. God and the devil are not equal opponents, as the author of Morals clearly shows. He stresses the almost complete dependence of the devil on God, stating that He both reprehends his unjust ways, and urges against him the righteousness of His Saints, and lets him by permission try their innocence, and sometimes stops

28 St Gregory the Great, Morals..., XXXIII, XXXVII, 63, ŹMon 78, 96. Here, St Gregory the Great compares earthly thoughts to the smoke that hinders the contemplation of the Creator. He is always present in the mind of the world's people, but it does attack spiritual people as well.

29 Ibidem, XXXIII, II, 4, ŹMon 78, 15.

30 Ibidem, XII, XXXIV, 39, ŹMon 44, 143-144.

31 Ibidem, XIII, XXXIV, 39, ŹMon 44, 144.

32 Ibidem, XXXIII, II, 4, ŹMon 78, 15.

${ }^{33}$ Cf. L. Nieścior, Implikacje moralne nauki o czasie w „,Moraliach” św. Grzegorza Wielkiego, „Teologia Patrystyczna” 2 (2005), 68. 
Bóg może z łatwością powstrzymać wszelkie działania szatana na każdym etapie kuszenia ${ }^{37}$. Złe duchy zatem nie mogą kusić ludzi, jeśli Bóg na to nie dopuści ${ }^{38}$.

Ojciec Kościoła nie poprzestaje jednak na stwierdzeniu, że Bóg przyzwala na pokusy. Analizuje on wszelkie działanie szatana, by wskazać jego związek ze Stwórcą: Wola szatana zawsze jest niegodziwa, ale jego moc nie jest nigdy bezprawna; sam decyduje o swojej woli, lecz moc posiada od Pana ${ }^{39}$. W zasadzkach złych duchów rozróżnione są zatem dwa elementy. Jedną z nich jest wola czynienia zła i deprawacji ludzi, którą posiadają demony. Drugą jest moc do czynienia tego, co zostało zamierzone. Pochodzi ona w całości od Boga, bez którego nic nie może istnieć. Dokonując takiego podziału, autor Moraliów chce ukazać, że Bóg nie jest bezpośrednią przyczyną zła, jakimi są pokusy, i jednocześnie podkreślić, iż są one od niego zależne $^{40}$. Dlatego doktor Kościoła wielokrotnie przedstawia Boga jako tego, który jest aktywnym sprawcą nieszczęść dotykających człowieka ${ }^{41}$.

Św. Grzegorz Wielki posuwa się nawet do tego, by relację szatana i Boga nazwać przymierzem (pactum) ${ }^{42}$. Użyte określenie ma wskazać, że w pokusach wypełnia się jednocześnie wola Stwórcy i złych duchów, więc w pewien sposób obie strony osiągają to, czego pragną bez sporu. Jednak Bóg pragnie zbawienia ludzi i sprawiedliwości, a szatan pragnie prowadzić ludzi ku złu i pozbawić ich wiecznego szczęścia. Wprawdzie tak różne cele wydają się niemożliwe do pogodzenia, jednak Opatrzność Boża może użyć nawet zła czynionego

7 Cfr. Ibidem, XXVIII, XXI, 45, ŹMon 77, 63.

38 Cfr. R. Sokołowski, Droga doskonalenia wedtug św. Grzegorza Wielkiego, Lublin 2014, 23.

${ }^{39}$ Grzegorz Wielki, Moralia, II, X, 17, ŹMon 39, 161.

40 Cfr. Grzegorz Wielki, Moralia, XVIII, II, 4, ŹMon 63, 63.

${ }^{41}$ Cfr. O. Kashchuk, Utrapienie a prawdziwe ziemskie szczęście w nauczaniu Grzegorza Wielkiego, VoxP 27 (2007) t. 50-51, 385.

${ }^{42}$ Użyte przez św. Grzegorza Wielkiego określenie, jak wiele innych, wynika z tekstu Księgi Hioba. Cfr. Grzegorz Wielki, Moralia, XXXIII, XIV, 28, ŹMon 78,52 . 
him that he dare not tempt them ${ }^{34}$. The use of the terms lets and stops aims to draw a clear line between Creator and creature. Satan's struggle and his hatred for the Almighty cannot threaten him, for God can easily stop all Satan's actions at any stage of temptation. ${ }^{35}$ Evil spirits may not therefore tempt people unless God lets them do so. ${ }^{36}$

However, the Father of the Church does not stop at saying that God accepts temptations. He analyses all Satan's actions to indicate his relationship with the Creator saying (...) the will of Satan is always evil, but his power is never unjust, for his will he derives from himself, but his power he derives from God. ${ }^{37}$ In the ambush of evil spirits, therefore, two elements can be distinguished. One is the will to do evil and deprave people, which demons possess. The latter is the power to do what is intended. It comes entirely from God, without whom nothing can exist. By making this division, the author of Morals intends to show that God is not the direct cause of wickedness, namely temptations, while emphasising that they are dependent on him. ${ }^{38}$ Accordingly, the Doctor of the Church repeatedly presents God as the one who is the active perpetrator of human misfortunes. ${ }^{39}$

St. Gregory the Great goes even further and calls the relationship between Satan and God a covenant (pactum) ${ }^{40}$. The term used is intended to indicate that in temptations the will of the Creator and the evil spirits is fulfilled at the same time, so in a way both parties achieve what they want without dispute. However, God wants the salvation and justice for people, and Satan wants to lead people

${ }^{34}$ St Gregory the Great, Morals..., II, VII, 12, ŹMon 39, 157.

${ }_{35}$ Cf. Ibidem, XXVIII, XXI, 45, ŹMon 77, 63.

${ }^{36}$ Cf. R. Sokołowski, Droga doskonalenia wedtug św. Grzegorza Wielkiego, Lublin 2014, 23.

37 St Gregory the Great, Morals..., II, X, 17, ŹMon 39, 161.

38 Cf. St Gregory the Great, Morals..., XVIII, II, 4, ŹMon 63, 63.

39 Cf. O. Kashchuk, Utrapienie a prawdziwe ziemskie szczęście w nauczaniu Grzegorza Wielkiego, VoxP 27 (2007) vol. 50-51, 385.

40 The term used by St Gregory the Great, like many others, is derived from the text of the Book of Job. Cf. St Gregory the Great, Morals..., XXXIII, XIV, 28, ŹMon 78, 52. 
przez szatana w zbawczym celu. Autor Moraliów stwierdza: To pozwolenie na kuszenie nazywa się przymierzem, bo chociaż realizuje się pragnienie kuszacego, to jednak w cudowny sposób wypetnia się wola sprawiedliwego Rządcy ${ }^{43}$. Zatem „korzyścią”, którą odnoszą złe duchy z zawartego przymierza, jest możliwość kuszenia w wyznaczonych przez Boga granicach. Mimo pewnego ograniczenia mogą one wykonywać swoje działanie, wynikające z nienawiści do Boga i jego dzieła i zmierzające u swoich podstaw do potępienia człowieka. Niewspółmiernie większe korzyści odnosi Bóg. Pozwala na kuszenie człowieka w konkretnych warunkach i tak wspiera swoją łaską ludzi, by ostatecznie uskutecznić miłosierdzie i sprawiedliwość w ich życiu ${ }^{44}$. Tak więc początkowo złą intencję pokusy Bóg różnymi sposobami potrafi prowadzić do dobrego skutku. Tę niewspółmierną korzyść ojciec Kościoła opisuje, stwierdzając: Stuży więc zgodnie z przymierzem ten, kto, mając pozwolenie na spetnianie własnej woli, jest skrępowany wola Bożego zamystu, i gdy gorliwie kusi wybranych, to nieświadomie tym kuszeniem (...) wzmacnia ich ${ }^{45}$. Łączy on ze sobą określenia służby i przymierza, wskazując, że choć szatan postrzega siebie w swojej pysze jako równorzędnego Bogu, to jest jedynie jego sługą, gdyż swoim działaniem nieświadomie wypełnia wolę Stwórcy ${ }^{46}$. W ten sposób działanie złych duchów często zamiast pierwotnego celu, którym jest sprzeciwianie się Bogu i potępienie człowieka osiąga skutek całkowicie odwrotne, prowadzący do uświęcenia ludzi.

${ }^{43}$ Ibidem, XXXIII, XIV, 28, ŹMon 78, 53.

${ }^{44}$ Cfr. O. Kashchuk, Utrapienie a prawdziwe ziemskie szczęście w nauczaniu Grzegorza Wielkiego, VoxP 27 (2007) t. 50-51, 385-390.

45 Grzegorz Wielki, Moralia, XXXIII, XIV, 28, ŹMon 78, 53.

${ }^{46}$ Jeszcze dobitniej ukazuje to autor Moraliów, gdy stwierdza, iż nawet po paruzji szatan będzie służył Bogu. Potępienie i cierpienie wszystkich, którzy odwrócili się od Boga, będzie ukazywało sprawiedliwość Boga i będzie przyczyną jeszcze większej radości zbawionych. Cfr. Grzegorz Wielki, Moralia, XXXIII, XIV, 29, ŹMon 78, 54. 
to wickedness and deprive them of eternal happiness. Although such different aims seem irreconcilable, Divine Providence can even use the evil done by Satan for salvation. The author of Morals states This liberty to tempt is, therefore, called a 'covenant,' wherein the desire of the tempter is effected, and yet the will of the righteous Dispenser is thereby wonderfully fulfilled ${ }^{41}$. Therefore, the 'benefit' that the evil spirits gain from the covenant is the possibility of temptation within the limits set by God. Despite a certain limit, they may perform their actions, resulting from hatred of God and his work and aiming at condemning man at its base. God benefits disproportionately more. He allows people to be tempted in specific conditions and so supports them with his grace to ultimately ensure mercy and justice in their lives. Thus, God, in various ways, is able to lead to a good result, initially a bad intention of temptation. This disproportionate benefit is described by the Father of the Church, by stating He is, therefore, a servant by agreement, who when permitted to fulfil his own will, is restrained by the will of the counsel of heaven, so as willingly to tempt the Elect of God, as was before said, and unwittingly to prove them by his temptation. ${ }^{42} \mathrm{He}$ combines the terms of a service and a covenant, indicating that although Satan sees himself as equivalent to God in his own good pride, he is only his servant, as by his actions he unconsciously fulfils the will of the Creator ${ }^{43}$. In this way, the acting of evil spirits often has the opposite effect, leading to the sanctification of people, instead of the original purpose of opposing God and condemning man.

${ }^{41}$ Ibidem, XXXIII, XIV, 28, ŹMon 78, 53.

42 St Gregory the Great, Morals..., XXXIII, XIV, 28, ŹMon 78, 53.

43 This is even more evident when the author of the Morals states that, even after the parousia, Satan will be a servant to God. The condemnation and suffering of all those who have turned away from God will show the justice of God and will cause even greater joy for the saved. Cf. St Gregory the Great, Morals..., XXXIII, XIV, 29, ŹMon 78, 54. 


\section{CECHY KUSZENIA ZLEGO DUCHA}

Św. Grzegorz Wielki, opisując walkę szatana z Hiobem, dzieli ataki szatana na dwie główne grupy: Pradawny wróg zwykt na dwa sposoby doświadczać rodzaj ludzki. Próbuje mianowicie albo złamać serce stawiajacych mu opór udrękami, albo urobić je podszeptami ${ }^{47}$. Pierwszą próbą, której został poddany Hiob, była utrata majątku rodziny i zdrowia, czyli prześladowanie ze strony corpus diaboli. Gdy wiara biblijnego bohatera pozostaje wśród cierpień nienaruszona, zły duch sięga po bardziej wyrafinowane narzędzia kuszenia ${ }^{48}$. Są nimi próby podstępnego zwiedzenia człowieka ku złu, które, jak zauważa święty, są o wiele bardziej niebezpieczne dla człowieka. Dwoiste działanie szatana ma dotykać jednocześnie fizycznej i duchowej sfery człowieka, aby przez udręki i podszepty z jak największą siłą odwrócić człowieka od Boga.

Należy zauważyć, że w powyższej wypowiedzi doktor Kościoła nazywa obie napaści szatana kuszeniem (tentatio) w szerokim znaczeniu jako działanie złych duchów mające na celu odwrócenie człowieka od Boga. Celem tego artykułu jest omówienie kuszenia w znaczeniu węższym, dlatego analizowane są w niej myśli dotyczące demonicznych podszeptów (persuasio).

Cechą charakterystyczną demonicznego działania jest jego nieustanność. Wielu cnotliwych ludzi nie ulega pierwszym podszeptom szatana, tak jak silny zapaśnik pokonuje pierwszych wystawionych w zawodach przeciwników. W walce $\mathrm{z}$ nimi zły duch posługuje się wieloma pokusami, aby w końcu udało mu się trafić na ostabienie kondycji walczacego i zapaśnik zostat przynajmniej pokonany dzięki następstwu osób ${ }^{49}$. W innym miejscu św. Grzegorz Wielki porównuje złe duchy do cudzoziemców, którzy z ukrycia zasypują studnię wykopywaną przez Izaaka ${ }^{50}$, by wskazać, że w walce z demonami

\footnotetext{
47 Ibidem, III, VIII, 12, ŹMon 39, 232.

48 Ibidem, III, VIII, 12, ŹMon 39, 232. Cfr. Ibidem, IX, XXII, 34, ŹMon 41, 277.

49 Grzegorz Wielki, Moralia, X, I, 1 ŹMon 41, 349.

50 Ibidem, XXXI, XXVII, 53, ŹMon 77, 291.
} 


\section{CHARACTERISTICS OF TEMPTATION OF AN EVIL SPIRIT}

St. Gregory the Great, describing Satan's fight against Job, divides Satan's attacks into two main groups: The old adversary is wont to tempt mankind in two ways; viz. so as either to break the hearts of the stedfast by tribulation, or to melt them by persuasion..$^{44}$ The first attempt Job underwent was the loss of family property and health, that is, persecution by the corpus diaboli. When the faith of the biblical hero remains intact in the midst of suffering, the evil spirit reaches for more subtle appliances of temptation ${ }^{45}$. These are attempts to deceitfully lead man to wickedness, which, as the saint notes, are much more dangerous for man. Satan's dual action is intended to touch the physical and spiritual sphere of man at the same time, in order to turn man away from God with the greatest possible force through anguish and whispering.

It should be noted that in the above statement, the Doctor of the Church calls both Satan's attacks temptation (tentatio) in a broad sense as the action of evil spirits aimed at turning man away from God. The purpose of this article is to discuss temptation in a narrower sense, and therefore it analyses thoughts on demonic whispers (persuasio).

The hallmark of demonic action is its continuity. Many virtuous people do not succumb to the first whispers of Satan, just as a strong wrestler defeats his first opponents in the competition. In the fight against them, the evil spirit uses many temptations so that as each fresh opponent comes to the encounter, he who cannot be overcome by the nature of their powers, may at least be got the better of by the changing of the persons. ${ }^{46}$ In another place, St. Gregory the Great compares evil spirits to aliens who secretly cover the well dug by

${ }^{44}$ Ibidem, III, VIII, 12, ŹMon 39, 232.

45 Ibidem, III, VIII, 12, ŹMon 39, 232. Cf. Ibidem, IX, XXII, 34, ŹMon 41, 277.

46 St Gregory the Great, Morals..., X, I, 1 ŹMon 41, 349. 
potrzeba wytrwałości. Wierzący musi być w każdym momencie swojego życiu czujny i stawiać opór zasadzkom diabła ${ }^{51}$. Jeżeli po długiej walce ulegnie się słabości, to można utracić cały uzyskany dzięki niej postęp.

Słowa Księgi Hioba mówiące o Lewiatanie są dla autora Moraliów okazją do wskazania na kolejną cechę działania złego ducha, którą jest podstępność. Św. Grzegorz Wielki jednoznacznie interpretuje te fragmenty jako alegoryczne przedstawienie szatana i w toku wykładów używa określenia „Lewiatan”, by wskazać na upadłego anioła ${ }^{52}$. Doktor Kościoła zwraca uwagę na etymologię stosowanego terminu, twierdząc, że nazwę „Lewiatan” tłumaczy się jako „naddatek dla nich"53 (additamentum eorum). Stwierdza on także, iż powyższa nazwa jest stosowana w Piśmie Świętym ironicznie, bo gdy obiecat dodać to, czym nie byli, odebrat przez oszustwo nawet to, czym byli ${ }^{54}$.

Aby lepiej przedstawić istotę zasadzek szatana, która wyrażona zostaje w nazwie „Lewiatan”, św. Grzegorz Wielki sięga do opisu kuszenia Adama i Ewy, bo to, co nasz starodawny wróg uczynit w raju, czyni nieustannie każdego dnia ${ }^{55}$. Wąż, kusząc pierwszych rodziców, obiecał im bycie niczym Bóg, by podstępnie odebrać im nieśmiertelność i łaskę raju. Podobnie obecnie, zły duch kusi do zła tym, co wydaje się ludziom dobre, by odebrać im łaskę Bożą i możliwość osiągnięcia zbawienia ${ }^{56}$. Zatem w każdej pokusie szatan przedstawia się ludziom jako naddatek dla nich, by odebrać im to, co posiadają. Dodatkowo w innym miejscu doktor Kościoła

51 R. Sokołowski, op. cit., 25.

${ }^{52}$ Cfr. Grzegorz Wielki, Moralia, XXXIII, XXIV, 44, ŹMon 78, 74.

53 Ibidem, IV, IX, 15, ŹMon 39, 307. Tłumaczenie to zaczerpnięte jest z dzieł św. Hieronima. Cfr. Hieronim, De nominibus Hebraicis, PL 23, 839.

${ }^{54}$ Moralia, XXXIII, IX, 17, ŹMon 78, s. 37. Cfr. Ibidem, I, XXXVI, 53, ŹMon 39, 139.

${ }_{55}$ Ibidem, XXIV, VII, 14, ŹMon 75, 87.

56 Cfr. O. Kashchuk, Księga Rodzaju jako źródło duchowej inspiracji w „,Moralia in Iob” św. Grzegorza Wielkiego, „Biblica et Patristica Thoruniensia” 4 (2011), 346-347. 
Isaac ${ }^{47}$, to indicate that one needs to be persistent in the fight against demons. A believer must be vigilant at every moment of his life and resist ambushes of the devil ${ }^{48}$. And if, after a long struggle, you succumb your weakness, you can lose all the progress you have achieved through it.

The words of the Book of Job about Leviathan are an opportunity for the author of Morals to point to another feature of the action of the evil spirit, which is deception. St. Gregory the Great unequivocally interprets these passages as an allegorical representation of Satan, and in the course of his lectures he uses the term "Leviathan " to indicate the fallen ange ${ }^{49}$. The Doctor of the Church draws attention to the etymology of the term used, claiming that the name "Leviathan" is translated as "their addition" 50 (additamentum eorum). He also states that this name is used ironically in the Scriptures, for when he promised them to bestow that which they were not, he even took away by his craft that which they really were ${ }^{51}$.

In order to better present the essence of Satan's ambushes, which is expressed in the name "Leviathan", St. Gregory the Great refers to the description of the temptation of Adam and Eve, for what our ancient enemy ceases not daily to do the very same thing which he did in Paradise. ${ }^{52}$ The serpent, tempting his first parents, promised them to be like God, to deceitfully take away their immortality and the grace of paradise. Likewise, nowadays, an evil spirit tempts people to evil by what seems good to them to take away the grace of God and the opportunity to achieve salvation. ${ }^{53}$ So, in every temptation,

47 Ibidem, XXXI, XXVII, 53, ŹMon 77, 291.

48 R. Sokołowski, op. cit., 25.

49 Cf. St Gregory the Great, Morals..., XXXIII, XXIV, 44, ŹMon 78, 74.

50 Ibidem, IV, IX, 15, ŹMon 39, 307. Cf. Jerome, De nominibus Hebraicis, PL 23, 839 .

${ }^{51}$ Morals, XXXIII, IX, 17, ŹMon 78, s. 37. Cf. Ibidem, I, XXXVI, 53, ŹMon 39, 139.

52 Ibidem, XXIV, VII, 14, ŹMon 75, 87.

53 Cf. O. Kashchuk, Księga Rodzaju jako źródło duchowej inspiracji w „, Moralia in Iob” św. Grzegorza Wielkiego, „Biblica et Patristica Thoruniensia” 4 (2011), 
przedstawia demoniczne pokusy jako sidła ${ }^{57}$, w których przynętą jest pomyślność tego świata uzyskiwana w wyniku nieprawości ${ }^{58}$. Zły duch tak zastawia pułapkę, by pętla grzechu była niewidoczna dla człowieka. Wówczas poprzez tę przynętę, która z pożadaniem dostrzega, wciagana jest $w$ wine, której nie dostrzega $a^{59}$.

Cechą charakterystyczną pokus jest także ich gradacyjność. Grzech nie zdobywa władzy nad człowiekiem natychmiast, lecz opanowuje go stopniowo. Św. Grzegorz Wielki dużą uwagę przywiązuje do ukazania całego mechanizmu ludzkiego upadku w grzech i rozróżnia cztery etapy pokus: $W$ sercu można go [grzech] popetnić z powodu zachęty, upodobania, przyzwolenia i zuchwatego usprawiedliwienia. Zachęta przychodzi za pośrednictwem przeciwnika, upodobanie za pośrednictwem ciała, zgoda za pośrednictwem ducha, zaś zuchwate usprawiedliwienie poprzez pychę $e^{60}$. Wskazuje zatem, że początkiem upadku człowieka jest zachęta ze strony szatana, którą nazywamy pokusą (suggestio). Kolejne dwa etapy dokonują się za sprawą człowieka. Jeden z nich to czerpanie przyjemności (delectatio) z myśli podsuwanych przez szatana, które dokonuje się po części przez ciało skażone grzechem pierworodnym, a po części przez ludzki umysł ${ }^{61}$. Drugi, pociągający już za sobą grzech uczynkiem, a nie samą myślą, to uległość człowieka wobec podsuwanego mu zła (consensus). Pyszne usprawiedliwianie (defensionis audacia) swojej winy jest już skutkiem wady nabytej przez ludzkie grzechy, prowadzącym do kolejnych złych czynów ${ }^{62}$. Zastosowany przez ojca Kościoła podział

57 Powyższe porównanie występuje w związku z Hi 18, 8-9.

58 Grzegorz Wielki, Moralia, XIV, XIII, 15, ŹMon 44, 166. Zob. Cfr. L. Bielas, Chrześcijanin a dobra materialne w myśli św. Grzegorza Wielkiego, „Teologia Patrystyczna" 2 (2005), 119-131.

59 Ibidem, XIV, XIII, 15, ŹMon 44, 167. Cfr. A. Wilczyński, Rola „discretio” wświetle pism św. Grzegorza Wielkiego, „Kieleckie Studia Teologiczne” 12 (2013), 258-259.

${ }^{60}$ Grzegorz Wielki, Moralia, IV, XXVII, 49, ŹMon 39, 335. Cfr. Ibidem, XXXII, XIX, 33, ŹMon 77, 388; R. Sokołowski, op. cit., 24.

${ }^{61}$ Cfr. Grzegorz Wielki, Moralia, III, XXXII, 62, ŹMon 39, 279.

${ }^{62}$ Cfr. Ibidem, IV, XXVII, 50, ŹMon 39, 337. 
Satan presents himself to people as an addition to take away from them what they have. Furthermore, in another place, the Doctor of the Church presents demonic temptations as a snare ${ }^{54}$, in which from the comeliness of the good he may measure the extent of his own deformity. ${ }^{55}$ The evil spirit sets a trap so that the loop of sin is invisible to man. For by those who possess every good quality in abundance, he rightly considers of what he is in want. And he beholds in their beauty his own deformity, which he is able to endure within himself, but not to perceive. ${ }^{56}$

The characteristic feature of temptations is also their gradation. Sin does not acquire power over man immediately, but it takes over him gradually. St. Gregory the Great pays particular attention to revealing the whole mechanism of human fall into sin and distinguishes four stages of temptation: For in the heart it is committed by the suggestion, the pleasure, the consent, and the boldness to defend. For the suggestion comes of the enemy; the pleasure, of the flesh; the consent, of the spirit; and boldness to uphold, of pride. ${ }^{57}$ Thus, he points out that the beginning of man's downfall is the encouragement from Satan, which we call temptation (suggestio). The next two steps are taken by man. One of them is the enjoyment (delectatio) of the thoughts suggested by Satan, which is carried out partly by the body tainted by original sin and partly by the human mind..$^{58}$ The second one, which already involves sin by deed rather than by thought, is man's submissiveness to the evil that is being imposed on

\section{6-347.}

54 This comparison is made in relation to Job 18, 8-9.

55 St Gregory the Great, Morals..., XIV, XIII, 15, ŹMon 44, 166. See Cf. L. Bielas, Chrześcijanin a dobra materialne w myśli św. Grzegorza Wielkiego, „Teologia Patrystyczna" 2 (2005), 119-131.

56 Ibidem, XIV, XIII, 15, ŹMon 44, 167. Cf. A. Wilczyński, Rola „,discretio” wświetle pism św. Grzegorza Wielkiego, „Kieleckie Studia Teologiczne” 12 (2013), 258-259.

57 St Gregory the Great, Morals..., IV, XXVII, 49, ŹMon 39, 335. Cf. Ibidem, XXXII, XIX, 33, ŹMon 77, 388; R. Sokołowski, op. cit., 24.

${ }^{58}$ Cf. St Gregory the Great, Morals..., III, XXXII, 62, ŹMon 39, 279. 
jest wyraźnie inspirowany nauczaniem św. Augustyna, gdyż terminy używane przez wspomnianych teologów są jednakowe ${ }^{63}$.

Dla św. Grzegorza Wielkiego powyższe rozróżnienie jest szczególnie istotne, gdyż pozwala odróżnić nieunikniony stan doznawania pokus od znajdowania w nich upodobania. Stwierdza on, że styszymy (...) głos dozorcy, gdy odczuwamy jego natarczywe kuszenie, lecz nie wysłuchujemy go, jeżeli sprzeciwiamy się jego napastliwości ${ }^{64}$. Diabeł nie ma tak wielkiej władzy nad człowiekiem, by zmusić go do popełnienia złego czynu. Może jedynie starać się wzbudzić w nim upodobanie i pragnienie danego uczynku. Dlatego doktor Kościoła wskazuje, że słusznie Hiob mówi o złym duchu, iż „współzranit nasze lędźwie”, bo my z własnej woli naśladujemy i realizujemy to, co on nam doradza ${ }^{65}$. Starając się podkreślić tę różnicę po stronie doznającego pokusy, autor Moraliów nazywa niegodziwe myśli odrzucane przez człowieka pokusa ludzka, a te, które osiągają zgodę ludzkiej woli - pokusa diabelska ${ }^{66}$.

Doktor Kościoła upatruje moment upadku człowieka przede wszystkim nie w dokonywanym czynie, lecz raczej w tym co go poprzedza, czyli w odnajdywaniu przyjemności w podsuwanej mu pokusie i zgodzie umysłu. Szatan najpierw prowadzi (...) myśli do złych pragnień, a potem te złe pragnienia prowadzi aż do najgorszych czynów ${ }^{67}$. Jednak nawet jeśli grzesznik nie ma możliwości zrealizowania swych złych pragnień poprzez czyny, to zadowala się samymi pragnieniami. Wyobraża on sobie pożądane zło i popełnia grzech mimo braku fizycznej możliwości. Św. Grzegorz Wielki jako wymowny przykład przytacza postępowanie ludzi uległych rozpuście,

${ }^{63}$ Cfr. Ibidem, IV, XXVII, 49, CCL 143; Augustyn, De sermone Domini in monte, 1, 34, PL 341246.

${ }^{64}$ Grzegorz Wielki, Moralia, IV, XXXV, 69, ŹMon 39, 365. W innym miejscu doktor Kościoła stwierdza, że upodobanie cielesne do grzechu zasługuje na mniejszą karę niż przyzwolenie duszy. Cfr. Ibidem, IV, XVIII, 34, ŹMon 39, 324.

${ }_{65}$ Ibidem, XIII, XVI, 19, ŹMon 44, 131. Cfr. Ibidem, XV, XXVI, 31, ŹMon 44, 249.

${ }^{66}$ Cfr. Ibidem, XXI, III, 7, ŹMon 63, 333.

${ }^{67}$ Ibidem, XXVII, XXVI, 50, ŹMon 75, 339. 
him. (consensus). Excuses full of pride (defensionis audacia) for one's guilt are the result of a defect acquired through human sins, leading to further evil deeds ${ }^{59}$. The division used by the Father of the Church is clearly inspired by the teachings of St Augustine, since the terms used by these theologians are the same ${ }^{60}$.

St. Gregory the Great finds this distinction particularly important because it allows us to distinguish between the inevitable state of experiencing temptation and finding pleasure in it. He states that we hear the voice of the exactor, when we are smitten with his temptation, but we do not bear it effectually [exaudimus] if we resist the hand that smites, for he 'hears' that feels the temptation, but he hears effectually who yields to the temptation. ${ }^{61}$ The devil does not have so much power over a man as to force him to commit an evil deed. He may only seek to arouse his liking and desire for the deed. That is why the Doctor of the Church points out that Job is right to speak of an evil spirit that he hath wounded my loins together, (...) in unity with him, because we are at the same time led to commit the evil deed of free will. ${ }^{62}$ In an attempt to underline this difference on the side of the tempted one, the author of Morals calls wicked thoughts rejected by man a human temptation, and those that reach the consent of the human will a devilish temptation. ${ }^{63}$

The Doctor of the Church sees the moment of man's downfall primarily not in the deed he performs, but rather in what precedes it, that is to say, in finding pleasure in the temptation and consent of the mind. Satan first leads on their thoughts to wicked desires, and afterwards leads their wicked desires even to the commission of most

${ }^{59}$ Cf. Ibidem, IV, XXVII, 50, ŹMon 39, 337.

${ }^{60}$ Cf. Ibidem, IV, XXVII, 49, CCL 143; Augustine, De sermone Domini in monte, 1, 34, PL 341246.

${ }^{61}$ St Gregory the Great, Morals..., IV, XXXV, 69, ŹMon 39, 365. The Doctor of the Church also states that bodily predilection for sin deserves less punishment than the consent of the soul. Cf. Ibidem, IV, XVIII, 34, ŹMon 39, 324.

${ }^{62}$ Ibidem, XIII, XVI, 19, ŹMon 44, 131. Cf. Ibidem, XV, XXVI, 31, ŹMon 44, 249.

${ }^{63}$ Cf. Ibidem, XXI, III, 7, ŹMon 63, 333. 
którzy rozkoszują się samym wyobrażaniem sobie przyjemności seksualnych ${ }^{68}$.

Początkiem grzechu jest upodobanie w grzesznych myślach, lecz grzesznik rzadko na nich tylko się zatrzymuje. $Z$ bagatelizowania narastających lekkich win człowiek niemal nieświadomie przechodzi w poważne grzechy. Św. Grzegorz Wielki stwierdza zatem: Dusza przecież nigdy nie leży tam, gdzie spadła; raz upadając z własnej woli, stacza się ku cięższym winom na skutek ciężaru własnej nieprawości, tak że spadajac $w$ dót, zawsze stacza się jeszcze głębiej ${ }^{69}$. Grzech posiada według autora Moraliów niezwykłą siłę ciążenia, która ściąga człowieka w dół z coraz większą mocą, dlatego szatan często zaczyna od bardzo łagodnych i łatwych do pokonania podszeptów. Doktor Kościoła wielokrotnie przestrzega przed lekceważeniem myśli kierujących się ku grzechowi ${ }^{70}$. Gdy człowiek zbagatelizuje zło i dopuści je do siebie, wtedy to, co na początku było małe i słabe niczym trawa, rośnie w siłę poprzez przyzwyczajenie i staje się olbrzymim cedrem, którego nie da się usunąć. Ta siła grzechu dopuszczonego do ludzkiego serca jest tak wielka, że doktor Kościoła stwierdza, iż już po pierwszym dokonanym grzechu zło panuje nad człowiekiem ${ }^{71}$.

Złe duchy nie poprzestają na doprowadzeniu człowieka do upadku, lecz starają się zatrzymać go z dala od Boga. Brak chęci poprawy i niedostrzeganie swoich błędów jest częstą postawą grzesznika: Powszechna wada rodzaju ludzkiego jest upadtszy i popetniwszy grzech, negować go i ukrywać to, co sie popetnito, a gdy zostanie to udowodnione - powiększać go przez usprawiedliwianie się ${ }^{72}$. Doktor Kościoła opisuje postępowanie grzeszników, którzy ulegając złym duchom, nie chcą przyznać się do popełnionego zła. Starają się oni przed samym sobą i innymi wypierać dokonanego czynu i zła, które

${ }^{68}$ Cfr. Ibidem, IV, XXX, 57, ŹMon 39, 347.

${ }^{69}$ Ibidem, XXXI, XV, 28, ŹMon 75, 265. Św. Grzegorz Wielki podkreśla, iż celem złego ducha jest doprowadzenie człowieka do największych grzechów pod koniec jego życia. Cfr. Ibidem, XXXII, XIX, 34, ŹMon 77, 388.

${ }^{70}$ Cfr. Ibidem, IV, XIX, 36, ŹMon 39, 325; XII, XVIII, 22, ŹMon 44, 85.

${ }^{71}$ Cfr. Ibidem, XXXII, XIX, 33, ŹMon 77, 387.

72 Ibidem, XXII, XV, 30, ŹMon 63, 402. 
sinful deeds. ${ }^{64}$ However, even if the sinner is unable to fulfil his evil desires through deeds, he is satisfied with the desires themselves. He imagines the desired evil and commits sin despite the lack of physical ability. As a meaningful example, St. Gregory the Great refers to the behaviour of people who are submissive to the despair and who delight in imagining sexual pleasures themselves. ${ }^{65}$

The beginning of sin is pleasure in sinful thoughts, but the sinner rarely stops right there. From the neglect of growing light faults, man almost unconsciously turns to serious sins. Therefore, St. Gregory the Great states that For a soul never lies in the spot where it has fallen; because having once fallen of its own accord, it is carried on to greater sins by the weight of its own iniquity, so that, as it sinks into the deep, it is ever overwhelmed still deeper. ${ }^{66}$ According to the author of Morals, sin has an extraordinary power of gravity that pulls a man down with an increasing power, which is why Satan often starts with very gentle whispers that are easy to overcome. The Doctor of the Church warns us many times against disregarding thoughts directed towards $\sin .{ }^{67}$ When man underestimates evil and allows it to happen, then what is small and weak at first, starts growing like grass through the habit, and becomes a giant cedar that cannot be removed. This force of sin admitted to the human heart is so great that the Doctor of the Church states that, after the first sin that was committed, evil reigns over man ${ }^{68}$.

Evil spirits do not stop at bringing man down, but try to keep him away from God. Lack of willingness to improve and failure to see their mistakes is a frequent attitude of the sinner, it is the accustomed evil practice of man's race, at once to commit sin keeping himself hidden from sight, and when committed to hide it by denying, and

${ }^{64}$ Ibidem, XXVII, XXVI, 50, ŹMon 75, 339.

${ }^{65}$ Cf. Ibidem, IV, XXX, 57, ŹMon 39, 347.

${ }^{66}$ Ibidem, XXXI, XV, 28, ŹMon 75, 265. St Gregory the Great stresses that the purpose of the evil spirit is to lead man to his greatest sins towards the end of his life. Cf. Ibidem, XXXII, XIX, 34, ŹMon 77, 388.

${ }^{67}$ Cf. Ibidem, IV, XIX, 36, ŹMon 39, 325; XII, XVIII, 22, ŹMon 44, 85.

${ }^{68}$ Cf. Ibidem, XXXII, XIX, 33, ŹMon 77, 387. 
ze sobą niesie. Przykładem tego jest postępowanie pierwszych rodziców, którzy ukryli się przed Bogiem. Nie chcąc być ocenieni za swoje postępowanie, uciekli przed wzrokiem innych, a następnie starali się usprawiedliwić, zrzucając winę na innych. Jednak człowiek nie może ukryć się przed Bogiem i sprawiedliwością: Chowając się ukrywa nie siebie przed Panem, ale Pana przed soba. Doprowadza nie do tego, że sam nie jest widziany, lecz do tego, że nie widzi Widzacego wszystko ${ }^{73}$. W obrazowy sposób ojciec Kościoła przedstawia bezcelowość działania człowieka, który jedynie szkodzi samemu sobie. Usprawiedliwianie się jedynie dodaje kolejne grzechy do już popełnionego i zamyka oczy grzesznika na popełnione zło, tym samym przeszkadzając w poprawie.

Św. Grzegorz Wielki wspomina też o innym działaniu demonów, które ma na celu powstrzymanie człowieka od poprawy: Podstępne sztuczki jego namów placza się ze sobq na skutek pogmatwanej intencji - tak, aby popetniali wiele grzechów w ten sposób, że gdyby przypadkiem chcieli uniknać winy, nie będa mogli uciec z sidła grzechu, nie wiktajac się $w$ inny ${ }^{74}$. Pokusy podsuwane przez demony grzesznikom nie są przypadkowe i często mają na celu stawianie człowieka w sytuacji, w której nie będzie mógł nie popełnić grzechu. Autor Moraliów podaje także przykłady takich sytuacji. Jednym z nich jest człowiek, który zobowiązał się do posłuszeństwa wobec złego przełożonego. Grzechem będzie w takim wypadku zarówno nieposłuszeństwo jak i posłuszeństwo, które nie będzie prowadziło do Boga. W podobnej sytuacji jest człowiek, który przekupstwem zdobył urząd kościelny. Nie może on bez winy opuścić powierzonego mu ludu, lecz winą będzie także sprawowanie urzędu zdobytego w niegodziwy sposób ${ }^{75}$.

Jedną z głównych cech działania złych duchów jest różnorodność. Przykładem wskazanym przez św. Grzegorza Wielkiego jest tu sam Hiob, który nie został zaatakowany przez szatana w jeden tylko

\footnotetext{
73 Ibidem, XXII, XV, 31, ŹMon 63, 403-404.

${ }^{74}$ Ibidem, XXXII, XX, 35, ŹMon 77, 390.

75 Cfr. Ibidem, XXXII, XX, 37-38, ŹMon 77, 391-392.
} 
when brought home to him, to multiply it by standing up for it. ${ }^{69}$ The Doctor of the Church describes the behaviour of sinners who, while succumbing to evil spirits, do not want to confess to their evil doings. What they attempt to do before themselves and before others is to suppress the deed and the evil that it brings with it. The behaviour of the first parents who hid themselves from God is such an example. They did not want to be judged for their acts, they fled from the eyes of others and then tried to justify themselves by blaming others. However, man cannot hide himself from God and justice: By which same concealment he has not hidden himself from the Lord, but the Lord from himself. For he manages that he should not see Him Who sees all things, not that he himself should not be seen. ${ }^{70}$ In an illustrative way, the Father of the Church depicts the pointlessness of human acts that only harm the man himself. Justification merely adds further sins to those already committed and closes the sinner's eyes to the evil committed, thus hindering the rectification.

St Gregory the Great also recalls another way in which demons act in order to stop people from improving: But the sinews of these stones are wrapped together, because the arguments of his suggestions are bound together by complicated devices; so as to make many sin in such a way, that, if they wish perchance to escape a sin, they cannot escape it without being entangled in another $\sin ^{71}$. The temptations that demons give to sinners are not accidental and often aim to put man in a situation where he is unable not to commit his sin. The author of Morals also gives examples of such situations. One of them is a man who submits himself to the authority of an evil superior. In such a case, both disobedience and obedience that will not lead to God will be a sin. Similarly, there is a man who acquired a church office through bribery. He cannot leave the flock committed to him without

69 Ibidem, XXII, XV, 30, ŹMon 63, 402.

70 Ibidem, XXII, XV, 31, ŹMon 63, 403-404.

71 Ibidem, XXXII, XX, 35, ŹMon 77, 390. 
sposób, lecz nieprzyjaciel (...) wytoczyt przeciwko niemu machiny wszelkiego rodzaju pokus: pozbawił go mienia, zabił synów, okaleczyt ciało, podburzył żonę, sprowadzit przyjaciół na pocieszenie, ale skłonit ich do ostrej nagany ${ }^{76}$. Autor wielokrotnie porównuje kuszenie do bitwy i oblężenia, mimo jedynie sporadycznego występowania tych paraboli w Księdze Hioba ${ }^{77}$. Ma ono na celu wskazanie, że pokusy są narzędziem walki między człowiekiem a złym duchem. Porównania te jednocześnie ujawniają, jak istotna jest strategia tej walki i znajomość planów nieprzyjaciela, gdyż jedno nieosłonięte miejsce w czasie ataku może stać się przyczyną upadku całego miasta ${ }^{78}$.

Autor Moraliów stara się przedstawić różne rodzaje zasadzek szatana, by uwrażliwić wierzących na chytrość złych duchów, ujawniającą się w wielości i różnorodności ich działań. Jednym z nich są pokusy dotykające doświadczonych chrześcijan. Wypróbowani wierzący odrzucają ziemskie pragnienia i opierają się pokusom, których zło jest ewidentne. Wobec nich szatan musi stosować innego rodzaju podstępy, dlatego św. Grzegorz Wielki rozróżnia kuszenie jawne i ukryte: Czasem bowiem [szatan] przedstawia się ludzkiemu umystowi taki, jaki jest-czyli zgubiony; czasem zaś ukazuje się jako anioł światta. (...) Niekiedy jawnie usituje przekonać do występku, niekiedy w swoich podszeptach ukrywa się pod płaszczykiem cnoty ${ }^{79}$. Ukazywanie się złego ducha jako zgubionego, czyli potępionego i zwróconego ku złu, to namowa człowieka do czegoś, co jest bezsprzecznie złem. Gdy chrześcijanin odrzuca takie podszepty, zły duch ukazuje się jako aniot światłości, nakłaniając do mniejszego dobra, które ostatecznie ma wzbudzić w człowieku upodobanie do zła.

${ }^{76}$ Ibidem, Przedmowa, IV, 9, ŹMon 39, 82-83. Cfr. Ibidem, III, X, 17, ŹMon 39, 239.

77 Cfr. A. Wilczyński, Symbolika agonistyczna i militarna w „Moraliach” św. Grzegorza Wielkiego, w: Grzegorz Wielki, Moralia. Komentarz do Ksiegi Hioba, ŹMon 78, Kraków 2016, 282-283.

${ }^{78}$ Cfr. Grzegorz Wielki, Moralia, XIX, XXI, 33, ŹMon 63, 204.

79 Ibidem, V, XXII, 43, ŹMon 39, 413. Cfr. Ibidem, XXXII, XXI, 40, ŹMon 77, 394. 
blame, but it will also be a sin to hold the authority of pastoral grace which he acquired in a wicked way. ${ }^{72}$

One of the main characteristics of evil spirits is diversity. An example given by St. Gregory the Great is Job himself, who was not attacked by Satan in one way only, but the enemy (...) set up against him the engines of temptation, spoiled his substance, slew his children, smote his body, instigated his wife, and while he brought his friends to console him, urged, them to the harshest upbraiding. ${ }^{73}$ The author repeatedly compares enticement to battle and siege, despite only occasional occurrence of these parables in the Book of Job ${ }^{74}$. It is intended to indicate that temptation is a tool for fighting between man and the evil spirit. At the same time, these comparisons reveal the importance of the strategy of this fight and of knowing the enemy's plans, since a single uncovered spot during an attack can cause the whole city to collapse ${ }^{75}$.

The author of Morals presents different kinds of Satan's ambushes in order to sensitise believers to the cunning of evil spirits, revealed in the multitude and diversity of their doings. One of them is the temptation affecting experienced Christians. Proven believers reject earthly desires and resist temptations, the evil of which is evident. Satan must use a different kind of deception against them, which is why St Gregory the Great distinguishes between open and hidden temptations: For one while he presents himself to man's senses lost as he is, one while he exhibits himself as an Angel of light (...) At one time he labours to win men to evil ways without disguise, at another time he cloaks himself in his promptings under the garb

72 Cf. Ibidem, XXXII, XX, 37-38, ŹMon 77, 391-392.

73 Ibidem, Preface, IV, 9, ŹMon 39, 82-83. Cf. Ibidem, III, X, 17, ŹMon 39, 239.

${ }^{74}$ Cf. A. Wilczyński, Symbolika agonistyczna i militarna $w$,,Moraliach” św. Grzegorza Wielkiego, in: St Gregory the Great, Morals on The Book of Job ŹMon 78, OXFORD, JOHN HENRY PARKER; J.G.F. AND J. RIVINGTON, LONDON. 1844, 282-283.

${ }^{75}$ Cf. St Gregory the Great, Morals..., XIX, XXI, 33, ŹMon 63, 204. 
Szatan może starać się wzbudzić w człowieku jakąś wadę przez jej podobieństwo do cnót lub próbować ukryć istniejącą już wadę pod pozorem cnoty. W taki sposób gniew może wydawać się sprawiedliwością, a ustępliwość - miłosierdziem ${ }^{80}$. Ten rodzaj pokus jest według św. Grzegorza Wielkiego szczególnie niebezpieczny, gdyż wierny może grzesząc sądzić, iż postępuje w cnocie. Ojciec Kościoła nie podaje wyraźnie sposobu odróżnienia cnót od udających je wad, lecz wskazuje na Boga jako na jedynego, który może zdemaskować ukryte $z^{\prime}{ }^{81}$. Taka uwaga jeszcze bardziej uwydatnia niebezpieczeństwo płynące ze wspomnianych pokus.

Kolejnym podziałem pokus stosowanym przez autora Moraliów jest rozróżnienie podszeptów na nagłe i długotrwałe: nagła pokusa, zaraz gdy się pojawi, zabija często nieprzygotowany umyst, zaś dtugotrwate kuszenie, które dłużej podsuwa niegodziwe rzeczy swymi namowami zabija jakjęzyk żmii ${ }^{82}$. Zależnie od okoliczności zły duch kusi w sposób niespodziewany, by pokonać człowieka nieprzygotowanego, lub stopniowo i niemal niezauważalnie skłania człowieka do grzechu. Działanie demonów jest nieprzewidywalne, gdyż mogą przez pewien czas kusić w sposób łagodny, by w odpowiednim czasie zaatakować nagłym podszeptem ${ }^{83}$. Modus operandi złych duchów jest przede wszystkim uzależniony od usposobienia i słabości kuszonego człowieka.

Św. Grzegorz Wielki w charakterystyczny dla siebie sposób wskazuje na znaczenie usposobienia i charakteru w życiu duchowym człowieka. Przestrzega on przed złymi duchami, które dostosowują swoje podszepty do słabości kuszonego ${ }^{84}$. I tak ludzie weseli są kuszeni do rozpusty, a smutni do gniewu. Bojaźliwi są narażeni na strach przed karami, a słuchający pochwał na popadnięcie w pychę.

${ }^{80}$ Cfr. Ibidem, III, XXXIII, 65, ŹMon 39, 280; XXXII, XXII, 45, ŹMon 77, 398.

81 Cfr. Ibidem, XXXIII, XXIV, 44, ŹMon 78, 75.

82 Ibidem, XV, XV, 19, ŹMon 44, 239. Cfr. Ibidem, XII, XVIII, 22, ŹMon 44, 84.

${ }^{83}$ Cfr. Ibidem, XV, XV, 19, ŹMon 44, 239.

${ }^{84}$ Cfr. Ibidem, XXXII, XXI, 40, ŹMon 77, 394-395. 
of virtue ${ }^{76}$ The appearance of an evil spirit as lost, that is to say, condemned and turned to evil, is an incitement to something that is undoubtedly evil. When a Christian rejects such whispers, the evil spirit appears as an Angel of light, urging the lesser good, which is ultimately to arouse man's predilection for evil.

Satan may try to arouse a flaw in man by its similarity to the virtues, or try to conceal an existing flaw under the guise of virtue. Thereby anger may seem like justice, and concession may seem like mercy. ${ }^{77}$ According to St. Gregory the Great, this type of temptation is particularly dangerous because the faithful may think that they are acting in virtue. The Father of the Church does not clearly state how to distinguish between the virtues and pretending vices, but points to God as the only one who can expose the hidden evil ${ }^{78}$. Such a remark highlights even more the danger of these temptations.

Another division of temptations used by the author of Morals is the distinction between gentle and prolonged whispers: a sudden temptation often as soon as it arises kills the soul off its guard, but a lengthened temptation, because it is longer recommending evil things by the suggesting of them, kills as does a viper with its tongue. ${ }^{79}$ Depending on the circumstances, an evil spirit tempts in an unexpected way to defeat an unprepared person, or gradually and almost imperceptibly induces a person to sin. The action of demons is unpredictable, as they can tempt in a gentle way for a certain period of time to attack in time with a sudden whisper ${ }^{80}$. Modus operandi of evil spirits is primarily dependent on the disposition and weakness of the tempted man.

St. Gregory the Great in a distinctive way points out the importance of disposition and character in the spiritual life of man. He warns

\footnotetext{
76 Ibidem, V, XXII, 43, ŹMon 39, 413. Cf. Ibidem, XXXII, XXI, 40, ŹMon 77, 394.

77 Cf. Ibidem, III, XXXIII, 65, ŹMon 39, 280; XXXII, XXII, 45, ŹMon 77, 398.

78 Cf. Ibidem, XXXIII, XXIV, 44, ŹMon 78, 75.

79 Ibidem, XV, XV, 19, ŹMon 44, 239. Cf. Ibidem, XII, XVIII, 22, ŹMon 44, 84.

${ }^{80}$ Cf. Ibidem, XV, XV, 19, ŹMon 44, 239.
} 
Nie uwięziłby ich łatwo, gdyby rozpustnym proponował łapówki albo chciwcom cielesne przyjemności ${ }^{85}$. Demoniczna koncentracja na słabości człowieka znacząco wzmacnia siłę pokus. Złe duchy, będące nawet po upadku niezwykle inteligentnymi aniołami, z łatwością są w stanie badać charakter człowieka, jego zalety i potencjalne wady.

\section{ZAKOŃCZENIE}

Rozważania poświęcone historii Hioba stanowiły dla św. Grzegorza Wielkiego okazję do rozważań na temat istoty pokus. Ich bezpośrednim sprawcą jest szatan - upadły anioł, który utraciwszy łaskę Bożą, stara się pozbawić jej jak największą ilość ludzi. W tym celu złe duchy wykorzystują swoją wiedzę na temat ludzkiej natury, by w jak najskuteczniejszy sposób oddziaływać na wierzących. Dlatego wykorzystują ludzi, którzy sprzeciwiają się Bogu, formując corpus diaboli-społeczność, której celem jest walka ze Stwórcą i oddanymi Mu ludźmi.

Św. Grzegorz Wielki wyraźnie ukazuje, że wszelkie namowy ku złu nie są przypadkowe, lecz wynikają z zaplanowanego działania diabła. Dokładny podział pokusy na cztery etapy pozwala także na wyraźne rozróżnienie winy moralnej w poszczególnych stanach wewnętrznych grzesznika. Jednocześnie autor Moraliów wskazując na wielkie niebezpieczeństwo płynące ze strony złych duchów, nieustannie podkreśla ich zależność od mocy Stwórcy. Wszystkie te myśli, zarówno najbardziej podstawowe jak i bardziej szczegółowe, doktor Kościoła przedstawia w sposób nadzwyczaj obrazowy i plastyczny. Tym samym Moralia, w średniowieczu cenione jako podręcznik duchowości, mogą także dla współczesnych czytelników stanowić źródło duchowych inspiracji.

${ }^{85}$ Ibidem, XXI, XXII, 45, ŹMon 63, 111. 
against evil spirits who adapt their whispers to the weaknesses of the tempted ${ }^{81}$. And so the merry people are tempted to debauchery and the sad to anger. The fearful are exposed to the fear of punishment, and those who listen to praise are exposed to pride. They would not be easily imprisoned if the fast were offered bribes, or the greedy were offered carnal pleasures. ${ }^{82}$ The demonic focus on human weakness significantly strengthens the power of temptation. Evil spirits, who are even after the fall extremely intelligent angels, are easily able to explore the character of man, his advantages and potential disadvantages.

\section{CONCLUSIONS}

The reflection on the history of Job was an opportunity for St. Gregory the Great to reflect on the essence of temptation. Their direct culprit is Satan, the fallen angel who, having lost the grace of God, seeks to deprive of it as many people as possible. To this end, evil spirits use their knowledge of human nature to influence believers in the most effective way. For this reason, they use people who oppose God to form corpus diaboli, i.e. a community whose aim is to fight against the Creator and people who are devoted to Him.

St. Gregory the Great clearly shows that any persuasion to evil is not accidental, but results from the devil's deliberate acting. The precise division of temptation into four stages also allows a clear distinction to be made between moral guilt in the sinner's individual internal states. At the same time, the author of Morals, pointing out the great danger coming from evil spirits, constantly stresses their dependence on the power of the Creator. All these thoughts, both the most basic and the most detailed, are presented by the Doctor of the Church in an extraordinary pictorial and artistic way. Thus Morals, valued as a textbook of spirituality in the Middle Ages, can also be a source of spiritual inspiration for contemporary readers.

\footnotetext{
${ }^{81}$ Cf. Ibidem, XXXII, XXI, 40, ŹMon 77, 394-395.

82 Ibidem, XXI, XXII, 45, ŹMon 63, 111.
} 


\section{Streszczenie}

Artykuł opisuje myśl św. Grzegorza Wielkiego na temat demonicznych pokus na podstawie Moraliów, czyli komentarza do Księgi Hioba. Podstawą nienawiści szatana do człowieka jest pragnienie przeciwstawienia się planowi Bożemu i odebranie człowiekowi możliwości zbawienia. Poprzez pokusy diabeł formuje corpus diaboli-społeczność przeciwstawiającą się swojemu Stwórcy. Całe działanie złych duchów jest jednak ograniczane przez Boga, tak iż nie jest ono w stanie zniszczyć planu Stwórcy, a nawet nieświadomie prowadzi ono do zbawienia wielu ludzi. W dalszej części artykułu przedstawione są podstawowe cechy pokus, poprzez których omówienie św. Grzegorz Wielki stara się uwrażliwić wierzących na subtelne działania złych duchów, które obiecując ulotne dobro odbierają człowiekowi łaskę Bożą.

Słowa klucze: pokusa, Grzegorz Wielki, szatan, Moralia, Księga Hioba, corpus diaboli

\section{Nota o autorze}

Karol Kisiel - ur. 1996 r., magister teologii, absolwent Uniwersytetu Kardynała Stefana Wyszyńskiego w Warszawie.

\section{Bibliografia}

Źródła

Pismo Święte Starego i Nowego Testamentu w przekładzie z języków oryginalnych,

Wyd. 5., Poznań 2007.

Augustyn, Enarrationes in Psalmos, PL 36, 67-1028; 37, 1035-1968.

Augustyn De sermone Domini in monte, PL 34, 1229-1307.

Grzegorz Wielki, Moralia in Iob, CCL 143-143B, Turnhout 1979-1985; Moralia.

Komentarz do Księgi Hioba, tłum. zbior., Kraków, ŹMon 39 (2013): I-V; ŹMon

41 (2006): VI-X; ŹMon 44 (2007): XI-XVI; ŹMon 63 (2013): XVII-XXII; ŹMon 75 (2015): XXIII-XXVII; ŹMon 77 (2016): XXVIII-XXXII; ŹMon 78 (2016): XXXIII-XXXV.

Hieronim, De nominibus Hebraicis, PL 23, 771-858.

Sun Tzu, Sun Pin, Sztuka Wojny, tłum. D. Bakalarz, Gliwice 2014. 


\title{
Summary
}

The article describes the thought of St. Gregory the Great on the subject of demonic temptations based on the Morals - commentary on the Book of Job. The basis of Satan's hatred for man is the desire to oppose God's plan and to deprive man of the possibility of salvation. Through temptations, the wickedness forms corpus diaboli, i.e. a community opposing its Creator. However, all evil spirits are limited by God, so that they are not able to destroy the Creator's plan, and even unknowingly lead to the salvation of many people. The rest of the article presents the basic features of temptations through which St. Gregory the Great tries to sensitize believers to the subtle actions of evil spirits who, promising ephemeral good, deprive man of God's grace.

Keywords: temptation, Gregory the Great, devil, Morals, Book of Job, corpus diaboli

\begin{abstract}
About the author
Karol Kisiel - born in 1996, Master of Theology, graduate of the Cardinal Stefan Wyszyński University in Warsaw.
\end{abstract}

\section{Bibliography}

Sources

Holy Scripture of the Old and New Testaments, https://www.biblegateway.com Augustine, Enarrationes in Psalmos, PL 36, 67-1028; 37, 1035-1968.

Augustine De sermone Domini in monte, PL 34, 1229-1307.

ST. GREGORY THE GREAT, MORALS ON THE BOOK OF JOB OXFORD, JOHN

HENRY PARKER; J.G.F. AND J. RIVINGTON, LONDON. 1844, ŹMon 39 (2013): I-V; ŹMon 41 (2006): VI-X; ŹMon 44 (2007): XI-XVI; ŹMon 63 (2013): XVII-XXII; ŹMon 75 (2015): XXIII-XXVII; ŹMon 77 (2016): XXVIII-XXXII; ŹMon 78 (2016): XXXIII-XXXV.

Jerome, De nominibus Hebraicis, PL 23, 771-858.

Sun Tzu, Sun Pin, The Art of War, Publisher : Hachette India (January 1, 2018)

Studies:

Bielas Lucjan, Chrześcijanin a dobra materialne w myśli św. Grzegorza Wielkiego, „Teologia Patrystyczna” 2 (2005), pp. 119-131. 
Opracowania

Bielas Lucjan, Chrześcijanin a dobra materialne w myśli św. Grzegorza Wielkiego, „Teologia Patrystyczna” 2 (2005), s. 119-131.

Cremascoli Giuseppe, Corpus diaboli. Sulla demonologia di Gregorio Magno w: Il diavolo nel medioevo. Atti del XLIX Convegno storico internazionale. Todi, 14-17 ottobre 2012, Spoleto 2013, s. 55-75.

Kashchuk Oleksandr, Księga Rodzaju jako źródło duchowej inspiracji w „, Moralia in Iob” 'sw. Grzegorza Wielkiego, „Biblica et Patristica Thoruniensia” 4 (2011), s. 341-360.

Kashchuk Oleksandr, Utrapienie a prawdziwe ziemskie szczęście w nauczaniu Grzegorza Wielkiego, VoxP 27 (2007) t. 50-51, s. 379-395.

Markus Robert Austin, Grzegorz Wielki, tłum. Nehring Przemysław, Warszawa, 2003.

Nieścior Leon, Implikacje moralne nauki o czasie w „Moraliach” św. Grzegorza Wielkiego, „Teologia Patrystyczna” 2 (2005), s. 63-93.

Rosik Seweryn, Finalizm życia chrześcijańskiego w świetle twórczości papieża Grzegorza Wielkiego, Lublin 1980.

Sokołowski Radosław, Droga doskonalenia wedtug św. Grzegorza Wielkiego, Lublin 2014.

Wilczyński Adam, Rola ,discretio” w świetle pism św. Grzegorza Wielkiego, „Kieleckie Studia Teologiczne” 12 (2013), s. 255-262.

Wilczyński Adam, Symbolika agonistyczna i militarna w "Moraliach" św. Grzegorza Wielkiego, w: Grzegorz Wielki, Moralia. Komentarz do Księgi Hioba, ŹMon 78, Kraków 2016, s. 281-310.

Wykaz skrótów

CCL - Corpus Christianorum, Series Latina, Turnhout 1953-

PL - Patrologiae cursus completus. Series Latina, Paris 1841-1855

VoxP - Vox Patrum, Lublin 1981-

ŹMon - Źródła Monastyczne, Tyniec/Kraków 1993- 
Cremascoli Giuseppe, Corpus diaboli. Sulla demonologia di Gregorio Magno w: Il diavolo nel medioevo. Atti del XLIX Convegno storico internazionale. Todi, 14-17 ottobre 2012, Spoleto 2013, pp. 55-75.

Kashchuk Oleksandr, Księga Rodzaju jako źródło duchowej inspiracji w „,Moralia in Iob” św. Grzegorza Wielkiego, „Biblica et Patristica Thoruniensia” 4 (2011), pp. 341-360.

Kashchuk Oleksandr, Utrapienie a prawdziwe ziemskie szczęście w nauczaniu Grzegorza Wielkiego, VoxP 27 (2007) vol. 50-51, pp. 379-395.

Markus Robert Austin, Gregory the Great and His World, Cambridge University Press, 1997.

Nieścior Leon, Implikacje moralne nauki o czasie w „,Moraliach” św. Grzegorza Wielkiego, „Teologia Patrystyczna” 2 (2005), pp. 63-93.

Rosik Seweryn, Finalizm życia chrześcijańskiego w świetle twórczości papieża Grzegorza Wielkiego, Lublin 1980.

Sokołowski Radosław, Droga doskonalenia według św. Grzegorza Wielkiego, Lublin 2014.

Wilczyński Adam, Rola „discretio” w świetle pism św. Grzegorza Wielkiego, „Kieleckie Studia Teologiczne” 12 (2013), pp. 255-262.

Wilczyński Adam, Symbolika agonistyczna i militarna w "Moraliach” św. Grzegorza Wielkiego, in: Grzegorz Wielki, Moralia. Komentarz do Księgi Hioba, ŹMon 78, Kraków 2016, pp. 281-310.

Abbreviations

CCL - Corpus Christianorum, Series Latina, Turnhout 1953-

PL - Patrologiae cursus completus. Series Latina, Paris 1841-1855

VoxP - Vox Patrum, Lublin 1981-

ŹMon - Monastic Sources, Tyniec/Kraków 1993- 